\title{
Prevalence and Risk Factors for Complications in Patients with Nontransfusion Dependent Alpha- and Beta-Thalassemia
}

\author{
Poramed Winichakoon, ${ }^{1}$ Adisak Tantiworawit, ${ }^{1}$ \\ Thanawat Rattanathammethee, ${ }^{1}$ Sasinee Hantrakool, ${ }^{1}$ Chatree Chai-Adisaksopha, ${ }^{1}$ \\ Ekarat Rattarittamrong, ${ }^{1}$ Lalita Norasetthada, ${ }^{1}$ and Pimlak Charoenkwan ${ }^{2}$ \\ ${ }^{1}$ Division of Hematology, Department of Internal Medicine, Faculty of Medicine, Chiang Mai University, \\ 110 Intravaroros Road, A. Muang, Chiang Mai 50200, Thailand \\ ${ }^{2}$ Division of Hematology and Oncology, Department of Pediatrics, Faculty of Medicine, Chiang Mai University, \\ 110 Intravaroros Road, A. Muang, Chiang Mai 50200, Thailand
}

Correspondence should be addressed to Adisak Tantiworawit; atantiwo@yahoo.com

Received 31 May 2015; Accepted 5 November 2015

Academic Editor: Aurelio Maggio

Copyright (C) 2015 Poramed Winichakoon et al. This is an open access article distributed under the Creative Commons Attribution License, which permits unrestricted use, distribution, and reproduction in any medium, provided the original work is properly cited.

Background. Nontransfusion dependent thalassemia (NTDT) is a milder form of thalassemia that does not require regular transfusion. It is associated with many complications, which differ from that found in transfusion-dependent thalassemia (TDT). Currently available information is mostly derived from beta-NTDT; consequently, more data is needed to describe complications found in the alpha-NTDT form of this disease. Methods. We retrospectively reviewed the medical records of NTDT patients from January 2012 to December 2013. Complications related to thalassemia were reviewed and compared. Results. One hundred patients included 60 females with a median age of 38 years. The majority (54 patients) had alpha-thalassemia. Overall, 83 patients had one or more complications. The three most common complications were cholelithiasis (35\%), abnormal liver function (29\%), and extramedullary hematopoiesis (EMH) (25\%). EMH, cardiomyopathy, cholelithiasis, and pulmonary hypertension were more commonly seen in beta-thalassemia. Osteoporosis was the only complication that was more common in alpha-thalassemia. The risk factors significantly related to EMH were beta-thalassemia type and hemoglobin $<8 \mathrm{~g} / \mathrm{dL}$. The risk factors related to osteoporosis were female gender and age $>40$ years. Iron overload (ferritin $>800 \mathrm{ng} / \mathrm{mL}$ ) was the only risk factor for abnormal liver function. Conclusion. The prevalence of alpha-NTDT complications was lower and different from beta-thalassemia.

\section{Introduction}

Thalassemia is a well-known inherited hematologic disorder caused by a decrease or an absence of globin production [1]. Patients with thalassemia suffer from chronic hemolytic anemia and its sequelae. Thalassemia originates from varying genetic abnormalities that result in different clinical presentation. Nontransfusion dependent thalassemia (NTDT) or thalassemia intermedia (TI) is a milder form of thalassemia which does not require regular blood transfusion for survival. This group of thalassemia patients was recognized earlier as a TI but no consensus on diagnostic criteria has been reached due to high clinical variations ranging from asymptomatic to multiorgan involvement [2-9]. The terminology has been changed from TI to NTDT [10]. Generally patients with NTDT can maintain hemoglobin levels at $6-10 \mathrm{~g} / \mathrm{dL}$ with occasional blood transfusions that may be required with fever, infection, or pregnancy $[3,4,7,8,10]$. Complications of NTDT result from chronic hemolysis and tissue hypoxia, causing iron overload and problems in many organ systems $[5,6,8,11-20]$. According to the largest observational study on thalassemia intermedia (OPTIMAL CARE study; $n=$ 584 TI patients), the three most common complications were osteoporosis, extramedullary hematopoiesis (EMH), and hypogonadism, respectively [8].

Several complications that are associated with thalassemia intermedia are less frequently seen in thalassemia major, including EMH, leg ulcers, gallstones, and thrombophilia [8]. 
TABLE 1: Clinical definition required to confirm identified complications.

\begin{tabular}{|c|c|}
\hline Complications & Definition \\
\hline Extramedullary hematopoiesis (EMH) & Physical or radiologic evidence of extramedullary hematopoietic foci with or without symptoms \\
\hline Pulmonary hypertension (PHT) & $\begin{array}{l}\text { Systolic pulmonary artery pressure }>35 \mathrm{mmHg} \text {, which corresponds to a tricuspid regurgitant } \\
\text { velocity on Doppler echocardiography of }>2.8 \mathrm{~m} / \mathrm{s} \text { plus exertional dyspnea without evidence of } \\
\text { left heart disease }\end{array}$ \\
\hline Thrombosis & Compression ultrasonography, contrast venography, or angiography evidence of thrombus \\
\hline Cardiomyopathy & $\begin{array}{l}\text { Echocardiographic, electrodiagnostic, or radiologic evidence of pathological change of } \\
\text { myocardium such as hypertrophy, dilatation, or restriction }\end{array}$ \\
\hline Cholelithiasis & Radiologic evidence of gallbladder stones \\
\hline Abnormal liver function & $\mathrm{ALT}>50 \mathrm{U} / \mathrm{L}$ \\
\hline Pseudoxanthoma elasticum (PXE) & Histopathologic evidence of pathological change in elastic fibers to inelastic tissue \\
\hline Leg ulcers & Ischemic or necrotic skin lesion on the lower extremity by general visual inspection \\
\hline Osteoporosis (OP) & Bone densitometry $T$ score $<2.5 \mathrm{SD}$ \\
\hline Abnormal plasma glucose & Fasting plasma glucose $>110 \mathrm{mg} / \mathrm{dL}$ at least one time \\
\hline Hypothyroidism & $\mathrm{TSH}>4.7 \mathrm{U} / \mathrm{L}$ and a free $\mathrm{T} 4>0.8 \mathrm{ng} / \mathrm{dL}$ \\
\hline Hypogonadism & $\begin{array}{l}\text { Females: }>13 \text { years, not yet Tanner B2 } \\
\text { (i.e., prepubertal breast development) } \\
\text { or }>14 \text { years requiring estrogen replacement therapy } \\
\text { or }>15 \text { years with primary amenorrhea; } \\
\text { males: }>14 \text { years, not yet Tanner G2 } \\
\text { (i.e., prepubertal genital development) } \\
\text { or on androgen replacement therapy } \\
\text { or }>17 \text { years, not yet Tanner G4 } \\
\text { (i.e., midpubertal genital development) }\end{array}$ \\
\hline Jron overload & Maximum ferritin level $>800 \mathrm{ng} / \mathrm{mL}$ with or without radiologic or histopathologic evidenc \\
\hline
\end{tabular}

Adapted from [8].

One of the most serious complications in NTDT is pulmonary hypertension which can be found in $11-50 \%$ of patients and leads to heart failure; the most common cause of death in NTDT patients $[3,4,6,8,11,13,14,16]$.

In our region, the proportion of patients classified by thalassemia type is changing due to advances in prenatal diagnoses and early detection. Higher numbers of NTDT patients are diagnosed and more fetuses with severe thalassemia are terminated.

Many previous studies aim to establish predictive factors for thalassemia complications and report that mechanisms for complications in thalassemia are multifactorial $[3,6,8,12$, 15, 21-27].

In our region, the prevalence of alpha-thalassemia is greater than that of beta-thalassemia which is different from the prevalence found in other regions [25, 26, 2830]. The lack of studies and clear guidelines in this group can present a significant clinical challenge. This study aims to elucidate the prevalence of complications and identify predictive factors affecting complication of both alpha- and beta-NTDT patients.

\section{Material and Method}

We retrospectively reviewed medical records of NTDT patients who attended the Chiang Mai University Hospital Adult Hematology Clinic for the two-year period from January 1, 2012, to December 31, 2013.
2.1. Population. The NTDT patients, age 15 years or older, were included in the study. NTDT is defined by thalassemia disease that does not require regular transfusion for survival [10]. However, the definition of transfusion varies among studies. We used the criteria of less than an average of three transfusions per year for the purpose of the study. The patient needed to visit the clinic at least once in order to be enrolled.

The diagnosis for the type of NTDT patients was made by hemoglobin analysis using a high-performance liquid column chromatography (HPLC) method. The molecular confirmation of $\alpha^{0}$-thalassemia (Southeast Asian or Thai deletion) and $\mathrm{HbCS}$ was done for cases with $\mathrm{HbH}$ disease and $\mathrm{HbH}$ with $\mathrm{Hb}$ Constant Spring ( $\mathrm{HbH} / \mathrm{CS}$ ) disease. Molecular diagnosis of beta-globin mutations was done in cases with beta NTDT when the results from hemoglobin analysis by HPLC method showed abnormal hemoglobin peak other than $\mathrm{Hb} \mathrm{E}$.

2.2. Data Collection. From January 1, 2012, to December 31, 2013, medical records of NTDT patients who met the inclusion criteria were reviewed. Data collected from medical records included demographic characteristics and diagnosis obtained by hemoglobin analysis. Also, findings from physical examination, laboratory investigations, and records of complications were recorded. The definition of conditions and complications in this study are shown in Table 1 [8]. 
2.3. Complications. Complications of NTDT patients were retrospectively collected from the medical record.

All NTDT patients had regular evaluation and investigations for these complications: three-monthly liver function tests and serum ferritin, annual tests for endocrine function which included fasting plasma glucose, thyroid function test, and hormonal assays for hypogonadism. Hepatitis B and C virus test were also done annually. Chest radiograph and echocardiogram were obtained for suspected cases of cardiomyopathy. Spine radiograph and bone mass densitometry were conducted in suspected osteoporosis cases.

For other complications such as extramedullary hematopoiesis (EMH), pulmonary hypertension (PHT), thrombosis, cardiomyopathy, cholelithiasis, pseudoxanthoma elasticum (PXE), leg ulcers, and osteoporosis (OP), the information was obtained retrospectively from medical records. Investigations for complications listed in Table 1 were conducted for putative cases where risk factors were present.

2.4. Statistical Analysis. Data were entered into database, crossed-checked, and analyzed using SPSS statistics software. Descriptive results of categorical and continuous variables were expressed as mean $( \pm \mathrm{SD})$ or median (range in continuous variables) depending on their distribution or as percentages of the group from which they were derived (categorical variables). The Chi-square test or Fisher exact test was used to compare categorical variables and Student's $t$-test was used to compare between continuous variables as appropriate. Variables that were significantly related to complications or with $p$ values less than 0.05 in the univariate analysis were entered into the multivariate analyses. Multivariate logistic regression analysis was used to identify independent risk factors for complications. Odds ratios (OR) and $95 \%$ confidence intervals (CI) were calculated for all associations that emerged. A $p$ value less than 0.05 was considered as statistically significant.

\section{Results}

3.1. Patient Characteristics. During the study period, 250 thalassemia patients attended our clinic. Of these, 100 NTDT patients who matched our inclusion criteria were included in this study, 60 patients (60\%) were female. Table 2 summarized patient demographics, underlying diseases and conditions, and clinical characteristics. The median age was 38 years (range 19-78 years). More than half of patients (54\%) were diagnosed with alpha-thalassemia. The mean ferritin level was $1,563.46 \mathrm{ng} / \mathrm{mL}$ while $76 \%$ and $44 \%$ of patients had ferritin levels more than 800 and 2,500 ng/mL, respectively. Chronic hepatitis B infection (27\%) was the most common comorbid condition.

3.2. Complications and Treatment Outcomes. Figure 1 summarizes patient treatments and the outcomes. Fifty-five of 100 patients $(55 \%)$ received iron chelation treatment for iron overload, and 33 of these patients (33\%) underwent a splenectomy. Overall, complications occurred in $83 \%$ of the study population. The three most common complications
TABLE 2: Characteristics of the study populations.

\begin{tabular}{|c|c|}
\hline Parameter & Frequency, number (\%) \\
\hline \multicolumn{2}{|l|}{ Gender } \\
\hline Male & $40(40 \%)$ \\
\hline Female & $60(60 \%)$ \\
\hline \multicolumn{2}{|l|}{ Age } \\
\hline$<40$ years & $54(54 \%)$ \\
\hline$\geq 40$ years & $46(46 \%)$ \\
\hline \multicolumn{2}{|l|}{ Region } \\
\hline Northern Thailand & 97 (97\%) \\
\hline Other & $3(3 \%)$ \\
\hline \multicolumn{2}{|l|}{ Comorbidities } \\
\hline Cerebrovascular disease & $2(2 \%)$ \\
\hline Chronic lung disease & $4(4 \%)$ \\
\hline Chronic kidney disease & $11(11 \%)$ \\
\hline Cirrhosis & $9(9 \%)$ \\
\hline Diabetes mellitus & $11(11 \%)$ \\
\hline Dyslipidemia & $2(2 \%)$ \\
\hline Endocrine disease & $16(16 \%)$ \\
\hline Eye-ENT disease & $4(4 \%)$ \\
\hline Gynecologic disease & $4(4 \%)$ \\
\hline Heart disease & $8(8 \%)$ \\
\hline Hypertension & $7(7 \%)$ \\
\hline HBV infection & $27(27 \%)$ \\
\hline HCV infection & $12(12 \%)$ \\
\hline Malignancy & $4(4 \%)$ \\
\hline Seizure & $4(4 \%)$ \\
\hline \multicolumn{2}{|l|}{ Personal history } \\
\hline Alcohol drinking & $14(14 \%)$ \\
\hline Herb use & $1(1 \%)$ \\
\hline Smoking & $4(4 \%)$ \\
\hline \multicolumn{2}{|l|}{ Thalassemia type } \\
\hline Alpha-thalassemia & $54(54 \%)$ \\
\hline Hemoglobin $\mathrm{H}$ & $38(38 \%)$ \\
\hline Hemoglobin H/CS & $16(16 \%)$ \\
\hline Beta-thalassemia & $46(46 \%)$ \\
\hline Beta-thalassemia and $\mathrm{HbE}$ disease & $36(36 \%)$ \\
\hline Beta-thalassemia intermedia & $10(10 \%)$ \\
\hline \multicolumn{2}{|l|}{ Hemoglobin } \\
\hline Mean hemoglobin level & $7.8 \mathrm{~g} / \mathrm{dL}$ \\
\hline \multicolumn{2}{|l|}{ Platelet } \\
\hline Mean platelet count & $330,900 / \mathrm{mm}^{3}$ \\
\hline \multicolumn{2}{|l|}{ Serum ferritin, ng/mL } \\
\hline Mean ferritin & $1,563.46 \mathrm{ng} / \mathrm{mL}$ \\
\hline Maximum ferritin $>800 \mathrm{ng} / \mathrm{mL}$ & $76(76 \%)$ \\
\hline
\end{tabular}

Hemoglobin $\mathrm{H} / \mathrm{CS}$ : hemoglobin $\mathrm{H}$ with $\mathrm{Hb}$ constant spring.

were cholelithiasis (35\%), abnormal liver function (29\%), and EMH (25\%). Other complications included osteoporosis (17\%), abnormal plasma glucose (16\%), pulmonary hypertension (14\%), hypothyroidism (13\%), cardiomyopathy (11\%), thrombosis (4\%), hypogonadism (7\%), and leg ulcers (2\%), respectively. 
TABLE 3: Treatment, outcome, and complications in study population.

\begin{tabular}{|c|c|c|c|}
\hline Parameter & $\begin{array}{c}\text { Frequency } \\
N=100(\%)\end{array}$ & $\begin{array}{l}\alpha \text {-Thal (\%) } \\
N=54(\%)\end{array}$ & $\begin{array}{l}\beta \text {-Thal (\%) } \\
N=46(\%)\end{array}$ \\
\hline \multicolumn{4}{|l|}{ Treatment } \\
\hline Antiplatelet & $26 \%$ & $3(5.6)$ & $23(50)$ \\
\hline Iron chelation & $55 \%$ & $21(38.9)$ & $34(73.9)$ \\
\hline Splenectomy & $33 \%$ & $8(14.8)$ & $25(54.3)$ \\
\hline \multicolumn{4}{|l|}{ Complications } \\
\hline Abnormal plasma glucose & $16 \%$ & $9(16.6)$ & $7(15.2)$ \\
\hline Abnormal liver function & $29 \%$ & $15(27.7)$ & $14(30.4)$ \\
\hline Cardiomyopathy & $11 \%$ & $3(5.5)$ & $8(17.4)$ \\
\hline Cholelithiasis & $35 \%$ & $15(27.7)$ & $20(43.5)$ \\
\hline Cholecystectomy & $25 \%$ & $10(18.5)$ & $15(32.6)$ \\
\hline EMH & $25 \%$ & $3(5.6)$ & $22(47.8)$ \\
\hline Hypothyroidism & $13 \%$ & $6(11.1)$ & $7(15.2)$ \\
\hline Hypogonadism & $7 \%$ & $2(3.7)$ & $5(10.9)$ \\
\hline Leg ulcers & $2 \%$ & $1(1.8)$ & $1(2.2)$ \\
\hline Osteoporosis & $17 \%$ & $11(20.4)$ & $6(13.0)$ \\
\hline PHT & $14 \%$ & $3(5.6)$ & $11(23.9)$ \\
\hline PXE & None & None & None \\
\hline Thrombosis & $4 \%$ & $2(3.7)$ & $2(4.3)$ \\
\hline Overall complications & $83 \%$ & $43(79.6)$ & $40(87)$ \\
\hline
\end{tabular}

EMH: extramedullary hematopoiesis, PHT: pulmonary hypertension, PXE: pseudoxanthoma elasticum, $\alpha$-Thal: alpha-thalassemia, and $\beta$-Thal: betathalassemia.

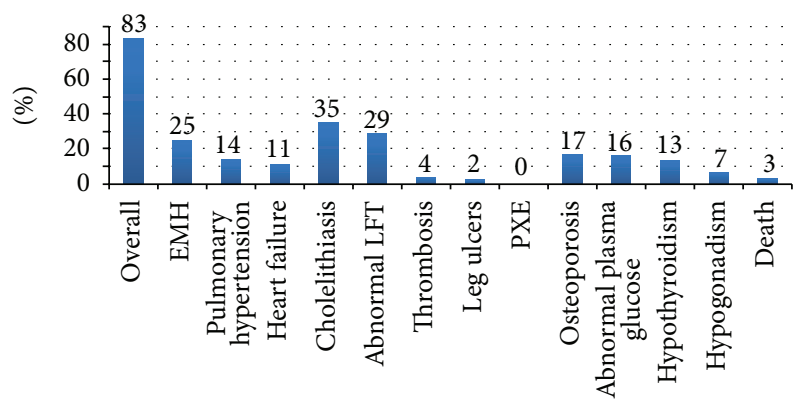

EMH: extramedullary hematopoiesis LFT: liver function test PXE: pseudoxanthoma elasticum

FIgURE 1: Percentage of complications and mortality in study population.

The radiologic investigations including plain film, CT scan, and MRI were used to detect EMH complications. Paravertebral soft tissue masses were found in nine patients, thalassemic bone change was found in five patients, and 11 patients had both paravertebral soft tissue and thalassemic bone change. All paravertebral soft tissue masses (20 patients) were found in the thoracic spine region. Thalassemic bone changes were found in the ribs (14 patients), femur (one patient), and spine (one patient).
3.3. Complications in Alpha and Beta-NTDT. The differences of complications classified by type of thalassemia were summarized in Table 3. The most common complications were similar between alpha- and beta-thalassemia groups: cholelithiasis and abnormal liver function test. However, the prevalence of cardiomyopathy, cholelithiasis, and pulmonary hypertension was higher in beta-thalassemia but the differences were not statistically significant. Osteoporosis was the only complication that was more commonly seen in alphathalassemia.

Though not statically significant, beta-thalassemia patients tended to have higher clinical severity and required further treatment more frequently than those with alphathalassemia. The mean ferritin level for the beta-thalassemia group $(1,971 \mathrm{ng} / \mathrm{mL})$ was higher than the alpha-thalassemia group $(1,202 \mathrm{ng} / \mathrm{mL})$. Seventy-four percent of beta-thalassemia patients received iron chelation as compared to $39 \%$ in alpha-thalassemia patients. Splenectomy was performed in $54.3 \%$ of beta-thalassemia and only $14.8 \%$ of alphathalassemia patients.

3.4. Risk Factors Affecting Complications. Results from the univariate analysis of significant risk factors for each complication were shown in Table 4. The following factors were significant in the model: extramedullary hematopoiesis, female gender $(p=0.05)$, beta-thalassemia $(p=0.031)$, hemoglobin level below $8 \mathrm{~g} / \mathrm{dL}(p=0.003)$, platelets above $400,000 / \mathrm{mm}^{3}$ ( $\left.p=0.025\right)$, maximum ferritin more than 
TABLE 4: Significant risk factors affecting complications from univariate analysis.

\begin{tabular}{|c|c|c|}
\hline Complication & Significant variables & $p$ value \\
\hline \multirow{7}{*}{ Extramedullary hematopoiesis } & Gender (female) & 0.050 \\
\hline & Thalassemia type (beta) & 0.031 \\
\hline & Hemoglobin $<8$ g/dL & 0.003 \\
\hline & Platelets $>400,000$ per cumm. & 0.025 \\
\hline & Maximum ferritin $>800 \mathrm{ng} / \mathrm{mL}$ & 0.004 \\
\hline & Splenectomy & 0.019 \\
\hline & Iron chelation & 0.001 \\
\hline Pulmonary hypertension & None & - \\
\hline Heart failure & Splenectomy & 0.035 \\
\hline Cholelithiasis & None & - \\
\hline \multirow{3}{*}{ Abnormal LFT $($ ALT $>50$ U/L) } & Iron chelation & 0.007 \\
\hline & Maximum ferritin $>800 \mathrm{ng} / \mathrm{mL}$ & 0.041 \\
\hline & HCV infection* ${ }^{*}$ & 0.143 \\
\hline \multirow{2}{*}{ Osteoporosis } & Gender (female) & 0.006 \\
\hline & Age $>40$ years & 0.003 \\
\hline Abnormal plasma glucose & None & - \\
\hline Hypothyroidism & None & - \\
\hline Hypogonadism & Splenectomy & 0.016 \\
\hline
\end{tabular}

${ }^{*} p$ value is not significant.

TABLE 5: Significant risk factors affecting complications from multivariate analysis.

\begin{tabular}{|c|c|c|c|c|}
\hline Complication & Significant variables & $p$ value & $95 \% \mathrm{CI}$ & Odd ratio \\
\hline \multirow{2}{*}{ Extramedullary hematopoiesis } & Thalassemia type (beta) & 0.031 & $1.173-27.971$ & 5.72 \\
\hline & Hemoglobin $<8$ g/dL & 0.007 & $1.736-31.252$ & 7.37 \\
\hline \multirow{2}{*}{ Osteoporosis } & Gender (female) & 0.014 & $1.514-38.604$ & 7.64 \\
\hline & Age $>40$ years & 0.017 & $1.313-16.506$ & 4.66 \\
\hline Abnormal liver function & Maximum ferritin $>800 \mathrm{ng} / \mathrm{mL}$ & 0.035 & $1.033-13.919$ & 3.79 \\
\hline
\end{tabular}

$800 \mathrm{ng} / \mathrm{mL}(p=0.004)$, iron chelation $(p=0.001)$, and splenectomy $(p=0.019)$. Splenectomy was also associated with heart failure $(p=0.035)$ and hypogonadism $(p=$ $0.016)$. The significant risk factors affecting abnormal liver function tests were a maximum ferritin more than $800 \mathrm{ng} / \mathrm{mL}$ $(p=0.041)$ and iron chelation $(p=0.007)$. There was no statistically significant difference for the relationship between $\mathrm{HCV}$ infection and abnormal liver function. Female gender $(p=0.006)$ and age over 40 years $(p=0.003)$ were significant factors for osteoporosis. No significant risk factors were found in pulmonary hypertension, cholelithiasis, abnormal plasma glucose, and hypothyroidism.

From multivariate analysis, significant risk factors affecting complications in EMH were beta-thalassemia with an odds ratio 5.7 (95\% CI 1.2-27.9, $p=0.03$ ) and hemoglobin level below $8 \mathrm{~g} / \mathrm{dL}$ with an odds ratio 7.4 (95\% CI 1.7-31.3, $p=0.007)$. Significant risk factors affecting complications in osteoporosis were female gender with an odds ratio 7.4 (95\% CI 1.5-38.6, $p=0.014$ ) and age more than 40 years with an odds ratio 4.6 (95\% CI 1.3-16.5, $p=0.017)$. Iron overload (ferritin $>800 \mathrm{ng} / \mathrm{mL}$ ) was the only risk factor for abnormal liver function with an odds ratio of 3.7 (95\% CI 1.013.9, $p=0.035$ ) (Table 5).

\section{Discussion}

NTDT is thought to be a less severe form of thalassemia since regular transfusions are not required. However, several studies revealed that many complications occur in patients with this form of thalassemia $[8,11,14,19]$. We compare prevalence and complications between alpha-NTDT and beta-NTDT and identify putative risk factors affecting complications in this group of patients.

Eighty-three percent of the study population (83 patients) experienced NTDT-related complications. Cholelithiasis (35\%), abnormal liver function (29\%), and EMH (25\%) were the three most common complications found in this study. These results were similar to that found in a study of 37 NTDT patients in Lebanon [6] where common complications were cholelithiasis, pulmonary hypertension, leg ulcer, and EMH. Another study from Taher et al. [8] found that osteoporosis, $\mathrm{EMH}$, hypogonadism, and cholelithiasis were the most common complications in NTDT. These findings indicate that complications from NTDT are quite different from TDT related complications which are mainly cardiomyopathy, endocrinopathy, and abnormal liver function [6].

Differences in the prevalence of complications across NTDT studies can be explained by the various complication 
definitions used, different in population numbers and type of NTDT (alpha or beta type). Our study had a higher portion of patients with alpha-NTDT which was different from previous studies $[6,8]$. This study was done only in adult patients who tended to have more complications.

Another reason that can explain the high prevalence of $\mathrm{EMH}$, cholelithiasis, and iron overload is that our study site is a referral center where most patients within the region with these complications were referred for further treatment.

The lower prevalence of thrombosis in our study may be due to a low incidence of thrombosis for the general Thai population when compared with other countries [31]. Moreover, thrombosis in thalassemia patients was largely disease related such as number of nucleated red cells, platelets $\geq 500 \times 10 / \mathrm{mm}^{3}$, and splenectomy. The lower number of mean platelet count and splenectomized patients from our study may also explain the lower incidence of thrombosis $[8,32]$. Due to incomplete medical records, our study did not have data regarding the number of nucleated red cells and years following splenectomy which are valuable predictors of thrombosis risk.

In this study, we compared the prevalence of complications between alpha-NTDT and beta-NTDT, which contribute new information to the existing body of research focused mainly on beta-NTDT patients $[4,8,15,16]$. In the multivariate analysis, beta-thalassemia was a significant risk factor for EMH complications $(47.8 \%$ in beta-NTDT versus $5.6 \%$ in alpha-NTDT). However, this significance disappeared when further subgroup analysis into alpha and beta-NTDT populations reduced the number of patients. The alpha-NTDT group tended to have less severe clinical manifestations than the beta group such as the degree of iron overload and iron chelation therapy and splenectomy frequency.

In the OPTIMAL CARE study, splenectomy had a significant effect on almost all complications in TI patients [8] while none of complications in our study related with this condition perhaps due to the low number of splenectomized patients. The rate of splenectomy in our study was 33\% compared to more than half in other studies [8].

Iron overload played a significant role in many TI related complications in previous studies and was also a risk factor for abnormal liver function tests in our study $[8,15,24,33,34]$. The incidence of iron overload was high in our study where $76 \%$ of patients had serum ferritin levels $>800 \mathrm{ng} / \mathrm{mL}$. Half of these patients received iron chelation therapy while the other half could not afford iron chelation therapy. Studies indicate serum ferritin levels may underestimate liver iron burden in NTDT [8], which can explain the high prevalence of iron overload and abnormal liver function in our study. Hence, iron overload is a critical issue for NTDT patients, even ones who are not receiving regular blood transfusions.

The major limitation of this study was the retrospective data collection for some complications such as pulmonary hypertension (PHT), thrombosis, cardiomyopathy, leg ulcers, and osteoporosis (OP). The information was obtained retrospectively from medical records but not routinely accessed, which may cause an underrepresentation of these complications. The incomplete medical records could prevent us from identifying predictive risk factors. Another limitation of this study was the small number of patients comprising the alphaNTDT and beta-NTDT subgroups.

In conclusion, despite variable clinical presentation and unclear diagnostic criteria, the prevalence of complications in NTDT was higher than and descriptively different from TDT. The prevalence of complications in alpha-NTDT was lower and descriptively different from beta-NTDT.

\section{Conflict of Interests}

The authors declare that there is no conflict of interests regarding the publication of this paper.

\section{Authors' Contribution}

Poramed Winichakoon was responsible for collecting the data, analyzing the data, interpreting the data, and writing the paper in part; Adisak Tantiworawit was responsible for conceiving and designing the study, obtaining funding and/or ethics approval, analyzing the data, interpreting the data, and writing the paper in whole; Thanawat Rattanathammethee, Ekarat Rattarittamrong, Lalita Norasetthada, Chatree ChaiAdisaksopha, Sasinee Hantrakool, and Pimlak Charoenkwan were responsible for revising the paper.

\section{Acknowledgments}

The authors thank Elizabeth Matovinovic (Faculty of Medicine, Research Administration, Chiang Mai University) for revising the paper. This work was supported by a grant from Chiang Mai University research fund.

\section{References}

[1] P. J. Giardina, "Thalassemia syndromes," in Hematology: Basic Principles and Practice, R. Hoffman, E. J. Benz, and S. S. Shattil, Eds., Elsevier Churchill Livingstone, Philadelphia, Pa, USA, 5th edition, 2008.

[2] C. Camaschella and M. D. Cappellini, "Thalassemia intermedia," Haematologica, vol. 80, no. 1, pp. 58-68, 1995.

[3] M. D. Cappellini, K. M. Musallam, and A. T. Taher, "Insight onto the pathophysiology and clinical complications of thalassemia intermedia," Hemoglobin, vol. 33, supplement 1, pp. S145-S159, 2009.

[4] F. El Rassi, M. D. Cappellini, A. Inati, and A. Taher, "Beta-thalassemia intermedia: an overview," Pediatric Annals, vol. 37, no. 5, pp. 322-328, 2008.

[5] K. M. Musallam, A. T. Taher, and E. A. Rachmilewitz, " $\beta$ thalassemia intermedia: a clinical perspective," Cold Spring Harbor Perspectives in Medicine, vol. 2, no. 7, Article ID a013482, 2012.

[6] A. Taher, H. Isma'eel, and M. D. Cappellini, "Thalassemia intermedia: revisited," Blood Cells, Molecules, and Diseases, vol. 37, no. 1, pp. 12-20, 2006.

[7] A. T. Taher, K. M. Musallam, and M. D. Cappellini, "Thalassaemia intermedia: an update," Mediterranean Journal of Hematology and Infectious Diseases, vol. 1, no. 1, Article ID e2009004, 2009. 
[8] A. T. Taher, K. M. Musallam, M. Karimi et al., "Overview on practices in thalassemia intermedia management aiming for lowering complication rates across a region of endemicity: the OPTIMAL CARE study," Blood, vol. 115, no. 10, pp. 1886-1892, 2010.

[9] J. E. Maakaron, M. D. Cappellini, and A. T. Taher, "An update on thalassemia intermedia," Journal Medical Libanais, vol. 61, no. 3, pp. 175-182, 2013.

[10] D. J. Weatherall, "The definition and epidemiology of nontransfusion-dependent thalassemia," Blood Reviews, vol. 26, supplement 1, pp. S3-S6, 2012.

[11] C. Borgna-Pignatti, M. Marsella, and N. Zanforlin, "The natural history of thalassemia intermedia," Annals of the New York Academy of Sciences, vol. 1202, pp. 214-220, 2010.

[12] H. Isma'eel, A. H. E. Chafic, F. E. Rassi et al., "Relation between iron-overload indices, cardiac echo-Doppler, and biochemical markers in thalassemia intermedia," American Journal of Cardiology, vol. 102, no. 3, pp. 363-367, 2008.

[13] M. Karimi, K. M. Musallam, M. D. Cappellini et al., "Risk factors for pulmonary hypertension in patients with $\beta$ thalassemia intermedia," European Journal of Internal Medicine, vol. 22, no. 6, pp. 607-610, 2011.

[14] B. N. Matta, K. M. Musallam, J. E. Maakaron, S. Koussa, and A. T. Taher, "A killer revealed: 10-year experience with betathalassemia intermedia," Hematology, vol. 19, no. 4, pp. 196-198, 2014.

[15] K. M. Musallam, M. D. Cappellini, and A. T. Taher, "Iron overload in $\beta$-thalassemia intermedia: an emerging concern," Current Opinion in Hematology, vol. 20, no. 3, pp. 187-192, 2013.

[16] A. Taher, F. El Rassi, H. Ismaeel, and A. Inati, "Complications of $\beta$-thalassemia intermedia: a 12-year Lebanese experience," American Journal of Hematology, vol. 83, no. 7, pp. 605-606, 2008.

[17] A. Taher, C. Hershko, and M. D. Cappellini, "Iron overload in thalassaemia intermedia: reassessment of iron chelation strategies," British Journal of Haematology, vol. 147, no. 5, pp. 634-640, 2009.

[18] A. T. Taher, K. M. Musallam, and A. Inati, “The hypercoagulable state in thalassemia intermedia," Hemoglobin, vol. 33, supplement 1, pp. S160-S169, 2009.

[19] J. E. Maakaron, "Complications and management of thalassemia intermedia," Journal of Applied Hematology, vol. 3, no. 4, pp. 143-146, 2012.

[20] M. D. Cappellini, K. M. Musallam, E. Poggiali, and A. T. Taher, "Hypercoagulability in non-transfusion-dependent thalassemia," Blood Reviews, vol. 26, no. 1, pp. S20-S23, 2012.

[21] C. Camaschella, U. Mazza, A. Roetto et al., "Genetic interactions in thalassemia intermedia: Analysis of $\beta$-mutations, $\alpha$ genotype, $\gamma$-promoters, and $\beta$-LCR hypersensitive sites 2 and 4 in Italian patients," American Journal of Hematology, vol. 48, no. 2, pp. 82-87, 1995.

[22] C. Camaschella, G. Saglio, A. Serra et al., "Molecular characterization of thalassemia intermedia in Italy, Birth Defects Original Article Series, vol. 23, no. 5, pp. 111-116, 1987.

[23] F. X. Kleber, L. Niemoller, and W. Doering, "Impact of converting enzyme inhibition on progression of chronic heart failure: results of the Munich Mild Heart Failure Trial," British Heart Journal, vol. 67, no. 4, pp. 289-296, 1992.

[24] K. M. Musallam, M. D. Cappellini, J. C. Wood, and A. T. Taher, "Iron overload in non-transfusion-dependent thalassemia: a clinical perspective," Blood Reviews, vol. 26, no. 1, pp. S16-S19, 2012.
[25] L. Nuntakarn, S. Fucharoen, G. Fucharoen, K. Sanchaisuriya, A. Jetsrisuparb, and S. Wiangnon, "Molecular, hematological and clinical aspects of thalassemia major and thalassemia intermedia associated with $\mathrm{Hb} \mathrm{E}$ - $\beta$-thalassemia in Northeast Thailand," Blood Cells, Molecules, and Diseases, vol. 42, no. 1, pp. 32-35, 2009.

[26] I. C. Verma, M. Kleanthous, R. Saxena et al., "Multicenter study of the molecular basis of thalassemia intermedia in different ethnic populations," Hemoglobin, vol. 31, no. 4, pp. 439-452, 2007.

[27] K. M. Musallam, A. Beydoun, R. Hourani et al., "Brain magnetic resonance angiography in splenectomized adults with $\beta$ thalassemia intermedia," European Journal of Haematology, vol. 87, no. 6, pp. 539-546, 2011.

[28] G. Fucharoen, H. Srivorakun, S. Singsanan, and S. Fucharoen, "Presumptive diagnosis of common haemoglobinopathies in Southeast Asia using a capillary electrophoresis system," International Journal of Laboratory Hematology, vol. 33, no. 4, pp. 424-433, 2011.

[29] S. Fucharoen, Thalassemia: From Molecular Biology to Clinical Medicine, Mahidol University, Bangkok, Thailand, 2007.

[30] S. Fucharoen and P. Winichagoon, "Haemoglobinopathies in Southeast Asia," Indian Journal of Medical Research, vol. 134, no. 10, pp. 498-506, 2011.

[31] P. Angchaisuksiri, V. Atichartakarn, K. Aryurachai et al., "Risk factors of venous thromboembolism in Thai patients," International Journal of Hematology, vol. 86, no. 5, pp. 397-402, 2007.

[32] A. T. Taher, K. M. Musallam, M. Karimi et al., "Splenectomy and thrombosis: the case of thalassemia intermedia," Journal of Thrombosis and Haemostasis, vol. 8, no. 10, pp. 2152-2158, 2010.

[33] E. B. Fung, P. R. Harmatz, P. D. K. Lee et al., "Increased prevalence of iron-overload associated endocrinopathy in thalassaemia versus sickle-cell disease," British Journal of Haematology, vol. 135, no. 4, pp. 574-582, 2006.

[34] K. M. Musallam, M. D. Cappellini, and A. T. Taher, "Evaluation of the $5 \mathrm{mg} / \mathrm{g}$ liver iron concentration threshold and its association with morbidity in patients with $\beta$-thalassemia intermedia," Blood Cells, Molecules, and Diseases, vol. 51, no. 1, pp. 35-38, 2013. 


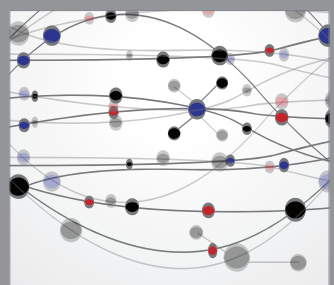

The Scientific World Journal
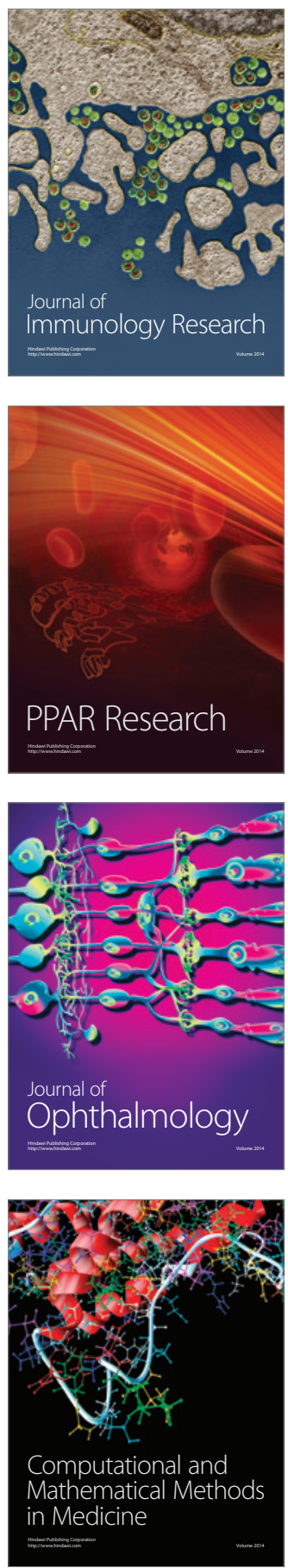

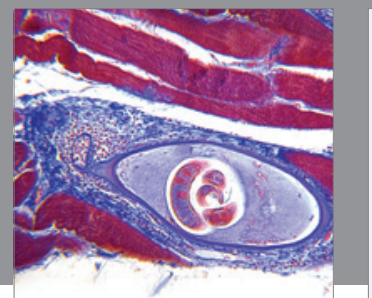

Gastroenterology

Research and Practice
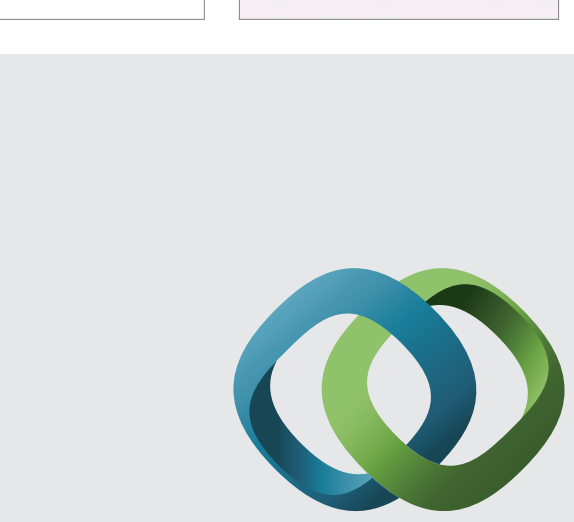

\section{Hindawi}

Submit your manuscripts at

http://www.hindawi.com
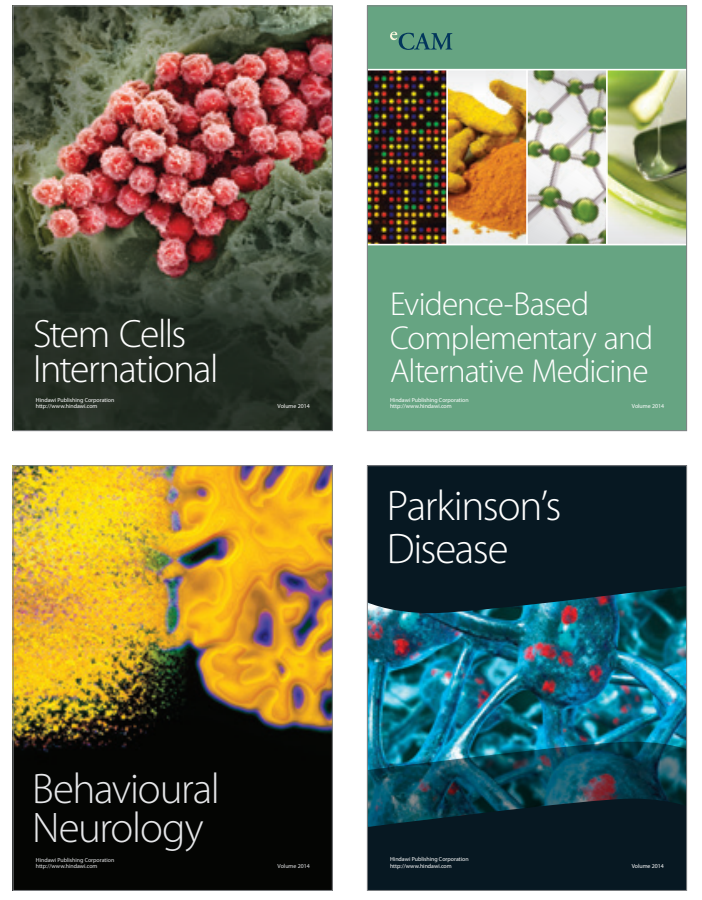
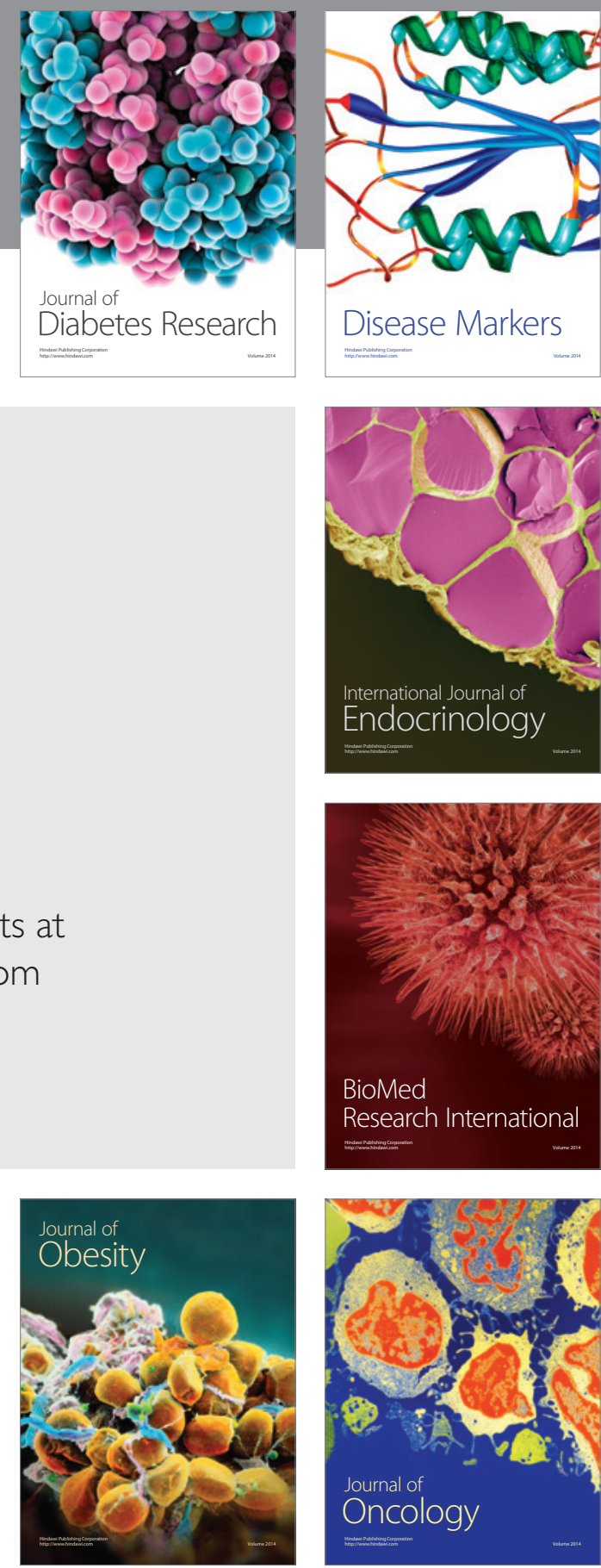

Disease Markers
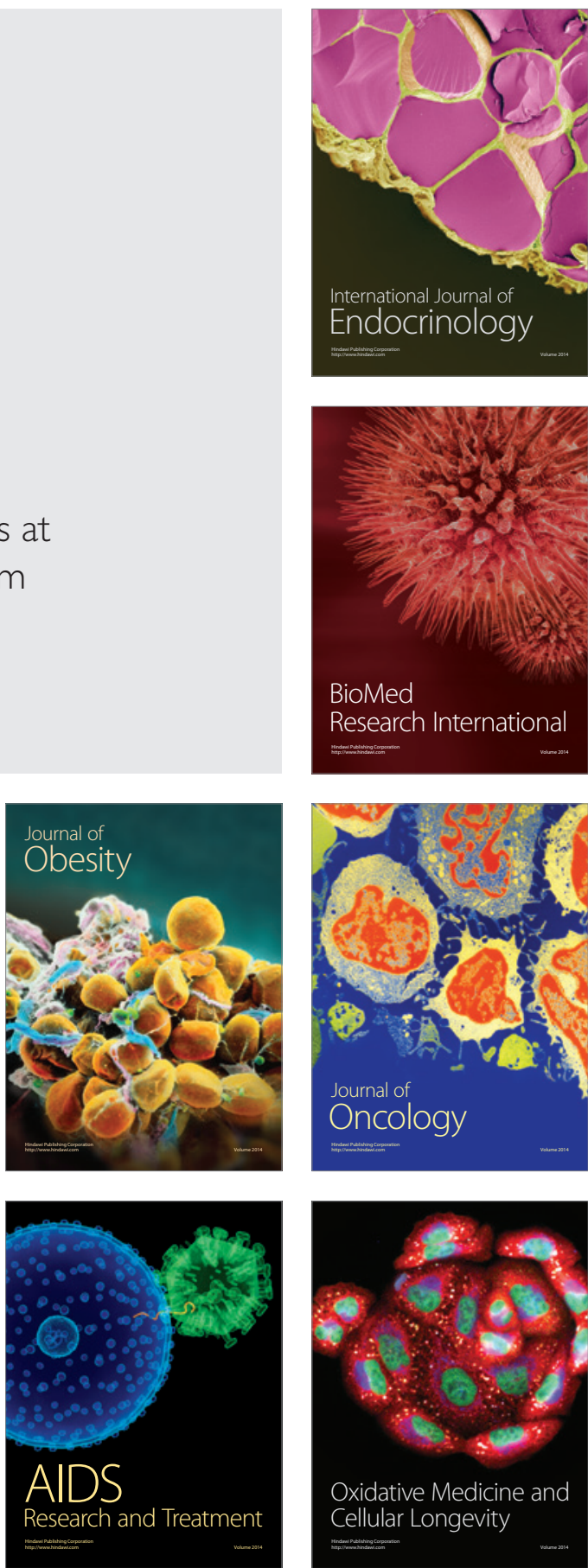